\title{
Sternal allograft transplantation for anterior chest wall reconstruction
}

\author{
N Asadi', A Dell'Amore, G Dolci, D Greco, G Caroli, C Ammari, A Bini, F Stella \\ From 23rd World Congress of the World Society of Cardio-Thoracic Surgeons \\ Split, Croatia. 12-15 September 2013
}

\section{Background}

Reconstruction of the chest wall after an anterior chest wall resection remains a difficult and controversial issue, therefore a correct reconstruction of these large resections is fundamental to avoid secondary complications. Different materials have been used to reconstruct the sternum, but none of them are considered the gold standard procedure. We propose a new technique using sternal-allograft to reconstruct the anterior chest wall after sternal resection.

\section{Methods}

The sternal allograft was harvested from a multi-tissue donor. After packaging, the allograft was stored at $-80^{\circ} \mathrm{C}$ until it's use. After a complete or partial resection of the sternum en-bloc with costal cartilage the sternal allograft was tailored to perfectly fit with chest wall defect and then the allograft was fixed using titanium bars and screws.

\section{Results}

Between June 2010 and February 2013, seven patients underwent sternectomy followed by anterior chest-wall reconstruction using sternal transplantation. Six patients were treated for neoplastic diseases, one patient for complete sternal dehiscence after sternotomy for cardiac surgery. In the post-operative period no major complications were reported and the patients were discharged after $9 \pm 2,4$ days. The mean follow-up time was $23.6 \pm$ 4.1 months. No mechanical failure or reconstruction related complications have been reported during followup and all patients are alive, in good clinical conditions, pain free and with normal pulmonary function tests.

\section{Conclusions}

The sternal allograft transplantation technique is simple and useful technique providing excellent functional and

\footnotetext{
* Correspondence: nizar.asadi@gmail.com

Thoracic Surgery, S. Orsola-Malpighi Hospital, University of Bologna, Italy
}

cosmetic results without complications during the follow-up.

Published: 11 September 2013

doi:10.1186/1749-8090-8-S1-0322

Cite this article as: Asadi et al:: Sternal allograft transplantation for anterior chest wall reconstruction. Journal of Cardiothoracic Surgery 2013 8(Suppl 1):0322.
Submit your next manuscript to BioMed Central and take full advantage of:

- Convenient online submission

- Thorough peer review

- No space constraints or color figure charges

- Immediate publication on acceptance

- Inclusion in PubMed, CAS, Scopus and Google Scholar

- Research which is freely available for redistribution
C Biomed Central
C Biomed Central 